\title{
Effect of Immobilization Support and Fermentation Temperature on Beer and Fermented Milk Aroma Profiles
}

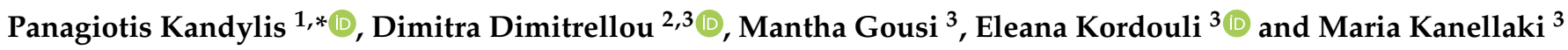 \\ 1 Laboratory of Oenology and Alcoholic Beverages, Department of Food Science and Technology, School of \\ Agriculture, Aristotle University of Thessaloniki, P.O. Box 235, 54124 Thessaloniki, Greece \\ 2 Department of Food Science and Technology, Ionian University, 28100 Argostoli, Kefalonia, Greece; \\ dimitrellou@gmail.com \\ 3 Department of Chemistry, University of Patras, 26504 Patras, Greece; mgousi_2@hotmail.com (M.G.); \\ ekordouli@upatras.gr (E.K.); m.kanellaki@upatras.gr (M.K.) \\ * Correspondence: pkandylis@agro.auth.gr; Tel.: +30-2310-991678
}

\section{check for} updates

Citation: Kandylis, P.; Dimitrellou, D.; Gousi, M.; Kordouli, E.; Kanellaki, M. Effect of Immobilization Support and Fermentation Temperature on Beer and Fermented Milk Aroma Profiles. Beverages 2021, 7, 47 https://doi.org/10.3390/ beverages7030047

Academic Editors: Antonio Morata, António Manuel Jordão,

Fernanda Cosme and Ileana Vigentin

Received: 29 April 2021

Accepted: 30 June 2021

Published: 5 July 2021

Publisher's Note: MDPI stays neutral with regard to jurisdictional claims in published maps and institutional affiliations.

Copyright: (c) 2021 by the authors. Licensee MDPI, Basel, Switzerland. This article is an open access article distributed under the terms and conditions of the Creative Commons Attribution (CC BY) license (https:// creativecommons.org/licenses/by/ $4.0 /)$.
Abstract: The food industry increasingly produces wastes like coconut and peanut shells. In addition, low temperature fermentation is always a challenge. Therefore, in the present study, a sustainable exploitation of these by-products is proposed through the production of carriers for immobilized cells of yeast and bacteria. The immobilized cells, after thermally drying, were evaluated for their efficiency in beer and milk fermentations respectively, in various fermentation temperatures and storage for up to three months. The beers and fermented milks were evaluated for their aroma and the results showed products of high quality. Coconut shells resulted in better products with increased fruity ester content in fermented milks and reduced dimethyl sulfite and vicinal diketones and increased ratio of esters to alcohol in beers. These results reveal the possibilities of immobilized cells in coconut and peanut shells for application in food industry, however, more research is needed to evaluate their effect on sensory characteristics and possible prebiotic and probiotic potential especially in the case of fermented milks.

Keywords: beverage; immobilization; GC-MS; volatile compounds; beer; fermented milk; Lacticaseibacillus casei; Saccharomyces cerevisiae; coconut shells; peanut shells

\section{Introduction}

A primary concern that has been steadily escalating in the last years is the waste exploitation in respect to conservation of the natural resources. A significant share of the waste sector is the agro-wastes, which may provide potential valuable components from a nutritional point of view, such as enzymes, fibers, vitamins, antioxidants, etc. This intriguing perspective can alter them from wastes, apart from an economical advantage, to environmental-friendly valuable products [1].

Peanut tree (Arachis hypogeae) and coconut palm (Cocos nucifera L.) are considered as edible nuts and their shells are major contributors to agro-wastes. More specifically, coconut solid waste is considered the by-product remaining after the coconut milk extraction and consists of the external hard shell and the fibrous husk that accounts for $15 \%$ of the whole nut [2]. Concerning the peanut, around $20 \%$ of the dried nut, called peanut shell or hull, remain after peanut processing [3]. Both peanut and coconut solid wastes have similar composition to wood, in the terms of lignin, cellulose and hemicellulose. Notably, an average composition of peanut shell is $26.4 \%, 40.5 \%, 14.7 \%$ [3] and of coconut shell $30.1 \%$, $19.8 \%, 68.7 \%$ [4] for lignin, cellulose and hemicellulose, respectively.

Many uses have been proposed for peanut and coconut shell exploitation in the literature, depending on their treatment. Interestingly, coconut solid waste is used as a construction material, i.e., as particle boards, masonry bricks, substitute for cement, etc., 
mainly in the Asian region, due to its low cost, abundancy and its thermo-mechanical properties $[5,6]$. Peanut and coconut shells have also been proposed as biosorbents of phenol compounds from olive mill wastewater $[7,8]$, for dye removal $[9,10]$ and for toxic elements removal [11,12], while many research papers proposed biochar from those materials as an alternative for waste management, for improving nutrient availability of the farmlands and therefore improving of crops [13,14].

The need for food products with improved nutritional value left behind the traditional fermentation and turned to low temperature fermentations because of the ever present advantages. Therefore, a challenge for the food industry is the production of novel supports suitable for the applied low temperatures. A given solution from the literature is the numerous applications of nano-tubular cellulose technology in food production, such as preservative delivery [15], non-thermal stabilization of liquid foods [16] and immobilization support for fermentation [17].

In the present study, in order to obtain tubular cellulose of peanut and coconut shells, they were subjected to delignification with $\mathrm{NaOH}$ solution, a more energy friendly treatment compared to the pyrolysis (a thermo-chemical process applied to organic materials in order to produce biochar at very high temperatures (between $280-420^{\circ} \mathrm{C}$ )) that primarily used for their exploitation [18].

A great number of agro-wastes have been studied as potential immobilization carriers for various microorganisms [19]. The organic nature via sugar composition of peanut and coconut shells makes them ideal microorganism assimilators [19]. Therefore, to the best of our knowledge, it is the first time that the tubular cellulose of peanut and coconut shells has been proposed as support for cell (Saccharomyces cerevisiae or Lacticaseibacillus casei) immobilization. To verify the energy-friendly trend of this study, an air circulation chamber was used in order to thermally dry the immobilized supports. Having, as a goal, the necessity of the food industry for dried and ready to use products, the experimental part was enhanced by studying the biocatalysts for a three months storage period at $5{ }^{\circ} \mathrm{C}$.

Since peanut and coconut solid wastes are obtained from non-hazardous agricultural sources, their exploitation should be applied in food production. Based on the aforementioned and the fact that these nut shells constitute an extremely low cost by-product and a high potential added value product, they are investigated in the present study with the view to utilize them in food production. More specifically, the aim of the present study was to evaluate the use of peanut and coconut solid wastes of food industry as supports for the development of new biocatalysts suitable for applications at low temperature fermentations resulting in improvement of the quality and nutritional value of beer (Saccharomyces cerevisiae) and fermented milk (Lacticaseibacillus casei ATCC 393) production.

\section{Materials and Methods}

\subsection{Materials and Support Preparation}

Coconut shells (Cocos nucifera) and peanut shells (Arachis) were collected by the local market (Achaia, Greece). After washed under running water, dried, checking and removing any foreign material, they were cut in small pieces.

Tubular cellulose (TC), from the above-mentioned raw materials, was produced after lignin removal. The solid substrates (300 g) delignified using 1\% w/v NaOH (3 L) and heated to $70{ }^{\circ} \mathrm{C}$ for $3 \mathrm{~h}$ in order to produce the TC. The delignified products rinsed with boiling deionized water [15]. The produced delignified TCs were sterilized by autoclaving at $120^{\circ} \mathrm{C}$ for $15 \mathrm{~min}$ and then dried at $37^{\circ} \mathrm{C}$ for $48 \mathrm{~h}$.

Bovine milk ( $37 \mathrm{~g} \mathrm{~L}^{-1}$ fat, $47 \mathrm{~g} \mathrm{~L}^{-1}$ sugars, $33 \mathrm{~g} \mathrm{~L}^{-1}$ protein) was obtained by a local market, while hopped wort (for lager beer) was kindly provided by Athenian Brewery S.A. (Achaia, Greece), filtered and pasteurized (pH 5.2 and $8.5^{\circ} \mathrm{Be}$ ). 


\subsection{Microorganisms and Culture Media}

The alcohol-resistant and psychrotolerant yeast strain Saccharomyces cerevisiae AXAZ-1 and the strain Lacticaseibacillus casei (formerly Lactobacillus casei) ATCC 393 (ATCC, Manassas, VA, USA) were used in the present study.

For culturing the yeast Saccharomyces cerevisiae AXAZ-1 the following medium was used containing (w/v): $0.1 \% \mathrm{KH}_{2} \mathrm{PO}_{4}, 0.1 \%\left(\mathrm{NH}_{4}\right)_{2} \mathrm{SO}_{4}, 0.5 \% \mathrm{MgSO} 4 \cdot 7 \mathrm{H}_{2} \mathrm{O}, 0.4 \%$ yeast extract, $4 \%$ glucose, at $30{ }^{\circ} \mathrm{C}$ with aeration $\left(500 \mathrm{~cm}^{3} \mathrm{~min}^{-1}, 7 \mathrm{mbar}\right)$, and harvested by centrifugation at $4000 \mathrm{rpm}$ for $10 \mathrm{~min}$.

Lacticaseibacillus casei ATCC 393 was grown in MRS broth (LabM, Lancashire, UK) without aeration at $37^{\circ} \mathrm{C}$ for $72 \mathrm{~h}$. The culture was harvested by centrifugation at $4000 \mathrm{rpm}$ for $10 \mathrm{~min}$.

All media were sterilized at $120^{\circ} \mathrm{C}$ at $1-1.5 \mathrm{~atm}$ for $15 \mathrm{~min}$ prior to use.

\subsection{Cell Immobilization}

Each of these TC products was used for cell entrapment in order to produce biocatalysts for low temperature brewing and fermented milk production. TC was added in S. cerevisiae AXAZ-1 culture or in L. casei ATCC 393 culture contained in the fermentation broths.

More specifically, immobilization was carried out by suspending $7 \mathrm{~g}$ (wet) of $S$. cerevisiae AXAZ-1 and $20 \mathrm{~g}$ of dried TC in $500 \mathrm{~mL}$ of $12 \%$ w/v glucose medium. The system remained for $16-24 \mathrm{~h}$ at $30^{\circ} \mathrm{C}$ until all sugar was utilized. Then the liquid was decanted and the biocatalyst was washed with $200 \mathrm{~mL}$ of fresh glucose medium [20]. L. casei ATCC 393 immobilization, was performed by dispersing $2 \mathrm{~g}$ (wet) L. casei ATCC 393 cells in $1 \mathrm{~L}$ sterilized MRS broth containing $20 \mathrm{~g}$ dried TC. After, the system remained for $48 \mathrm{~h}$ at $37^{\circ} \mathrm{C}$, the liquid decanted and the biocatalyst was washed with sterile 1/4 Ringer's solution [21].

For the enumeration of immobilized cells, representative $10 \mathrm{~g}$ portions of duplicate samples were blended with $90 \mathrm{~mL}$ of sterilized Ringer solution (1/4 strength) and subjected to serial dilutions. The number of immobilized cells was estimated as was described in previous studies [21,22].

\subsection{Thermal-Drying of Biocatalysts and Storage}

The new biocatalysts were thermally-dried at $38^{\circ} \mathrm{C}$ with air circulation for $24 \mathrm{~h}$ at an air chamber [23]. The thermally-dried biocatalysts were stored at $5{ }^{\circ} \mathrm{C}$ for up to 3 months.

\subsection{Brewing and Fermented Milk Production}

Fermented milks were produced using $10 \mathrm{~g}$ of dried TC and $500 \mathrm{~mL}$ of milk, while beers were produced using $20 \mathrm{~g}$ of dried TC and $500 \mathrm{~mL}$ of hopped wort. Fermentations were conducted at $5,10,15$ and $25^{\circ} \mathrm{C}$ in the case of beer and at 10,18 and $37^{\circ} \mathrm{C}$ in the case of fermented milk. The whole experimental design is presented in Figure 1.

\subsection{Analyses}

\subsubsection{TC Characterization}

X-ray powder diffractometry (XRD) was used to characterize the tubular cellulose on an Enraf Nonius FR590 diffractometer (Enraf-Nonius B.V., Rotterdam, The Netherlands) with CuKa radiation generation [24].

\subsubsection{Major Volatile Analysis of Beers by Gas-Chromatography}

The major volatiles of beers (diacetyl, 2,3-pentanedione, dimethyl sulfide, acetaldehyde, propanol, isobutyl alcohol, amyl alcohols, ethyl acetate, isoamyl acetate and ethyl hexanoate) were determined on an Agilent GC-7890-A GC system with an Agilent HP-5 column, an Agilent 7697-A headspace sampler, and flame ionization detector (FID) and electron capture detector (ECD) at 280 and $155^{\circ} \mathrm{C}$, respectively (Agilent Technologies Co., Los Angeles, CA, USA). Helium was used as carrier gas $\left(3 \mathrm{~mL} \mathrm{~min}^{-1}\right)$. The column temperature was set at $40^{\circ} \mathrm{C}$ for $8 \mathrm{~min}$, followed by a temperature gradient of $5^{\circ} \mathrm{C} \mathrm{min}-1$ 
to $60{ }^{\circ} \mathrm{C}$, and then $15^{\circ} \mathrm{C} \mathrm{min}-1$ to $170{ }^{\circ} \mathrm{C}$. Samples of $1 \mathrm{~mL}$ were injected into the column via the headspace sampler. Standard curves were constructed for quantitative analysis.

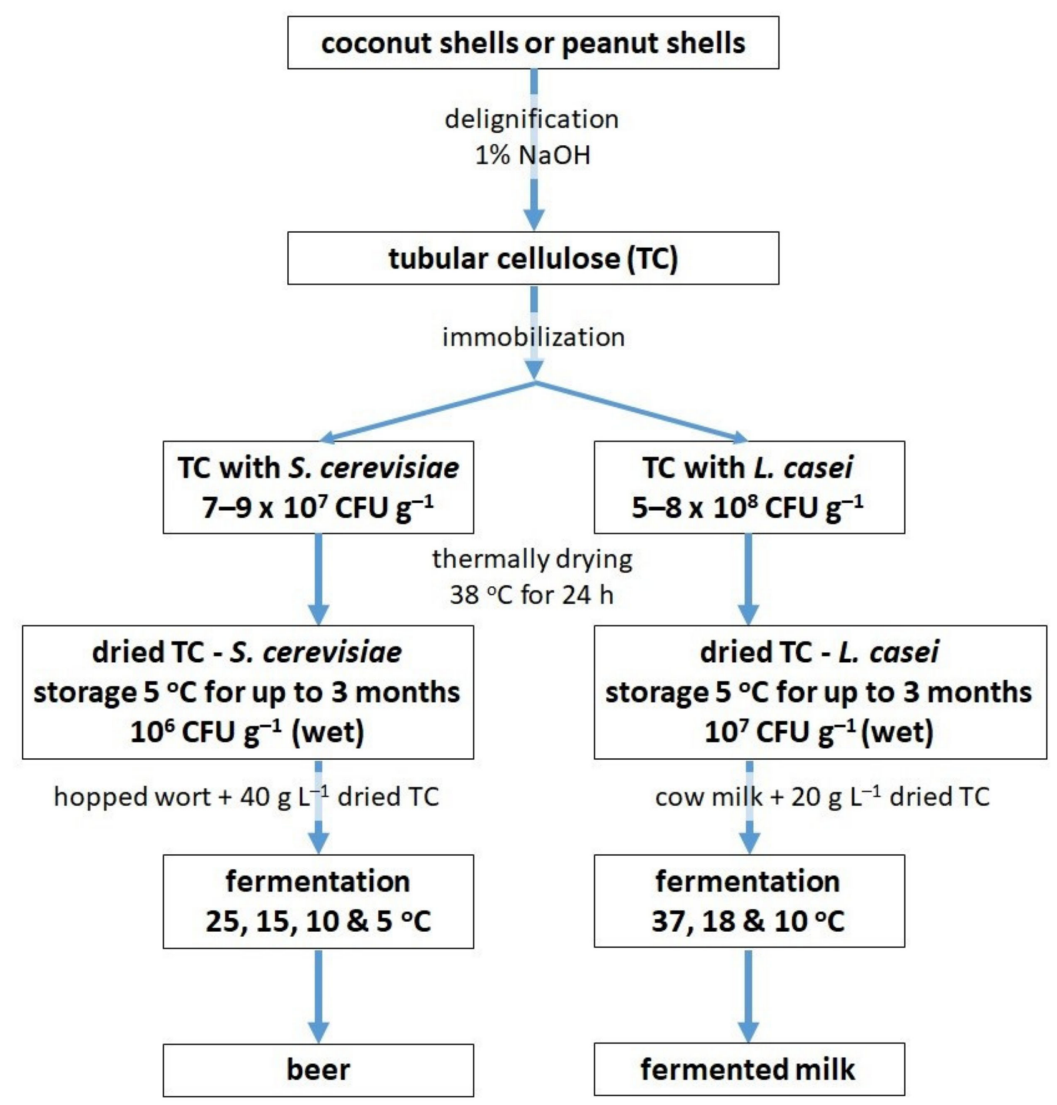

Figure 1. The production of beer and fermented milk with tubular cellulose.

\subsubsection{HS-SPME GC/MS Analysis}

Fermented milk samples were used to study the volatile composition by head space (HS) solid-phase microextraction (SPME) GC-MS analysis. The procedure described in a previous study [25] was followed, using $7 \mathrm{~g}$ of fermented milk. In the case of beer sample the procedure described in [20] was followed.

\subsection{Statistical Analysis}

The results were analyzed statistically by ANOVA. Tukey post-hoc test was used to determine significant differences among results (Statistica version 12.0, StatSoft Inc., Tulsa, OK, USA).

\section{Results and Discussion}

\subsection{XRD Characterization of Pretreated Coconut and Peanut Shells}

It is well-known that the X-ray diffraction patterns of untreated coconut shells present a large amorphous portion due to their high lignin content [26] around 34\% [27]. Tubular cellulose from coconut shells (TCCS) exhibited three main reflection peaks at $2 \theta=15.6^{\circ}$, $22.7^{\circ}$ and $34.6^{\circ}$ relative to the cellulose crystalline structure. The same is also observed in the case of untreated coconut shells [24], however in the case of TCCS narrower and more intense crystalline peaks were observed as a result of $\mathrm{NaOH}$ pretreatment that removed the lignin fraction. Similar results reported in a previous study using coconut husk fibers [26], but also in the case of peanut shells in the present study. The crystallinity degree in both samples was increased after pretreatment with $\mathrm{NaOH}$ indicating that the pretreatment was effective and the removal of lignin was obtained [28]. More specifically, the crystallinity 
degree was $39.9 \%$ in coconut shells and $67.7 \%$ in peanut shells after pretreatment, while in the untreated samples were $38.9 \%$ and $53.9 \%$, respectively $[26,28]$.

The new pretreated materials were evaluated for potential applications in food industries and therefore two well-known beverages were selected, beer (using yeast cells) and fermented milk (using lactic acid bacteria).

\subsection{Immobilization Efficiency}

The delignified material (coconut and peanut shells) was used for the immobilization of cells (S. cerevisiae and L. casei) in order to be capable for the production of several fermented foods. The immobilization was confirmed by the enumeration of immobilized cells. The results showed increased numbers of immobilized cells for both yeast and bacteria (7-9 $\times 10^{7} \mathrm{CFU} \mathrm{g}^{-1}$ and 5-8 $\times 10^{8} \mathrm{CFU} \mathrm{g}{ }^{-1}$ for S. cerevisiae and L. casei, respectively), in the same range of those reported in the literature with several supports like delignified wheat bran [21] and barley grains [22]. The application of thermal drying on the immobilized cells and their storage resulted in a slight reduction of viable cells $\left(10^{6} \mathrm{CFU} \mathrm{g}{ }^{-1}\right.$ and $10^{7} \mathrm{CFU}$ $\mathrm{g}^{-1}$ for S. cerevisiae and L. casei, respectively) as was also observed in the case of thermally dried immobilized kefir on casein [23].

\subsection{Beer}

\subsubsection{Major Volatile Compounds of Beers}

The major volatile compounds identified by gas chromatography using thermallydried immobilized yeast on coconut or peanut shells are presented in Tables 1 and 2, respectively. The results showed that the total higher alcohol content (propanol, isobutyl alcohol and amyl alcohols) in beers produced using thermally-dried immobilized cells was similar to those of previous studies at similar temperatures $[29,30]$. This group is the most abundant detected in beer, and originated mainly from the amino acid catabolism of brewing yeast [31]. The storage significantly affected $(p<0.05)$ the content of higher alcohols leading to lower concentrations after three months. In addition, in both cases, fermentation at lower temperature produced lower concentrations of higher alcohols. Propanol and isobutyl alcohol were detected in levels usually detected in beers and below their threshold values [31]. In contrast, the amyl alcohols were detected in concentrations higher than their threshold values, especially at high $\left(15-25^{\circ} \mathrm{C}\right)$ fermentation temperatures. The increased production of higher alcohols has been correlated with the promoted expression of BAT1 gene of $S$. cerevisiae at high temperatures [32]. 
Table 1. Major volatile compounds in beers produced using thermally dried immobilized S. cerevisiae on coconut shells.

\begin{tabular}{|c|c|c|c|c|c|c|c|c|c|c|c|}
\hline $\begin{array}{l}\text { Storage of IC } \\
\text { (Months) }\end{array}$ & $\begin{array}{l}\text { FT } \\
\left({ }^{\circ} \mathrm{C}\right)\end{array}$ & $\begin{array}{l}\text { Diacetyl } \\
\left(\mu \mathrm{g} \mathrm{L}^{-1}\right)\end{array}$ & $\begin{array}{c}2,3- \\
\text { Pentanedione } \\
\left(\mu \mathrm{g} \mathrm{L}^{-1}\right)\end{array}$ & $\begin{array}{c}\text { DMS } \\
\left(\mu \mathrm{g} \mathrm{L}^{-1}\right)\end{array}$ & $\begin{array}{l}\text { Acetaldehyde } \\
\left(\mathrm{mg} \mathrm{L}^{-1}\right)\end{array}$ & $\begin{array}{c}\text { Ethyl } \\
\text { Acetate } \\
\left(\mathrm{mg} \mathrm{L}^{-1}\right)\end{array}$ & $\begin{array}{l}\text { Propanol } \\
\left(\mathrm{mg} \mathrm{L}^{-1}\right)\end{array}$ & $\begin{array}{l}\text { Isobutyl } \\
\text { Alcohol } \\
\left(\mathrm{mg} \mathrm{L}^{-1}\right)\end{array}$ & $\begin{array}{c}\text { Amyl } \\
\text { Alcohol } \\
\left(\mathrm{mg} \mathrm{L}^{-1}\right)\end{array}$ & $\begin{array}{l}\text { Isoamyl } \\
\text { Acetate } \\
\left(\mathrm{mg} \mathrm{L}^{-1}\right)\end{array}$ & $\begin{array}{c}\text { Ethyl } \\
\text { Hexanoate } \\
\left(\mathrm{mg} \mathrm{L}^{-1}\right)\end{array}$ \\
\hline \multirow{4}{*}{0} & 25 & $33.8 \pm 2.0^{e f}$ & $24.8 \pm 1.5^{f}$ & $23.0 \pm 2.1^{\mathrm{e}}$ & $7.9 \pm 0.8^{b c d}$ & $60.8 \pm 7.5^{\text {def }}$ & $27.8 \pm 1.5^{\text {efg }}$ & $22.9 \pm 2.4^{b c}$ & $86.7 \pm 8.5^{a b}$ & $3.0 \pm 0.8^{b c}$ & $0.8 \pm 0.3$ \\
\hline & 15 & $31.3 \pm 2.3^{\text {def }}$ & $16.4 \pm 0.5^{\mathrm{de}}$ & $13.1 \pm 1.7^{\mathrm{bcd}}$ & $5.1 \pm 0.5^{\mathrm{ab}}$ & $51.1 \pm 5.5^{\mathrm{cde}}$ & $25.1 \pm 0.7$ def & $15.6 \pm 1.7^{\mathrm{ab}}$ & $86.0 \pm 6.5^{\mathrm{ab}}$ & $0.2 \pm 0.1^{\mathrm{a}}$ & $0.8 \pm 0.3$ \\
\hline & 10 & $29.0 \pm 1.5^{\text {cde }}$ & $8.7 \pm 0.4^{\mathrm{abc}}$ & $12.0 \pm 0.9 \mathrm{bc}$ & $8.5 \pm 0.5 \mathrm{bcd}$ & $35.5 \pm 2.1 \mathrm{abcd}$ & $22.2 \pm 0.6^{\text {cde }}$ & $13.5 \pm 0.9^{a}$ & $79.0 \pm 7.1^{\mathrm{ab}}$ & $0.5 \pm 0.2^{\mathrm{a}}$ & $0.3 \pm 0.1$ \\
\hline & 5 & $32.3 \pm 1.4^{\text {ef }}$ & $5.6 \pm 0.6^{\mathrm{ab}}$ & $10.1 \pm 0.7^{\mathrm{ab}}$ & $8.9 \pm 0.2^{\mathrm{cd}}$ & $22.5 \pm 1.5^{\mathrm{ab}}$ & $15.6 \pm 1.2^{\mathrm{ab}}$ & $8.4 \pm 0.2^{\mathrm{a}}$ & $52.5 \pm 2.3^{\mathrm{a}}$ & $0.9 \pm 0.3^{\mathrm{ab}}$ & $0.3 \pm 0.1$ \\
\hline \multirow{3}{*}{1} & 25 & $39.0 \pm 1.7^{f}$ & $21.3 \pm 2.0^{\text {ef }}$ & $18.8 \pm 1.1^{\mathrm{de}}$ & $9.3 \pm 0.3^{\mathrm{cd}}$ & $100.5 \pm 9.1^{\mathrm{g}}$ & $29.8 \pm 0.3^{\mathrm{fg}}$ & $29.6 \pm 2.1^{\mathrm{c}}$ & $87.9 \pm 9.1^{\mathrm{ab}}$ & $3.3 \pm 0.7^{b c}$ & $0.9 \pm 0.3$ \\
\hline & 10 & $31.3 \pm 0.9$ def & $11.0 \pm 1.6^{\mathrm{bcd}}$ & $14.2 \pm 0.9 \mathrm{bcd}$ & $4.1 \pm 0.2^{\mathrm{ab}}$ & $29.2 \pm 1.2^{a b c}$ & $13.2 \pm 1.0^{\mathrm{a}}$ & $7.9 \pm 0.6^{\mathrm{a}}$ & $69.0 \pm 4.1^{\mathrm{ab}}$ & $0.3 \pm 0.1^{\mathrm{a}}$ & $0.1 \pm 0.1$ \\
\hline & 5 & $22.2 \pm 0.5^{\mathrm{abc}}$ & $8.0 \pm 0.7 \mathrm{abc}$ & $12.1 \pm 0.4 \mathrm{bc}$ & $9.6 \pm 0.5^{\mathrm{cd}}$ & $28.4 \pm 2.6^{\mathrm{abc}}$ & $17.6 \pm 0.4 \mathrm{abc}$ & $10.8 \pm 0.9^{a}$ & $55.0 \pm 5.0^{\mathrm{a}}$ & $1.3 \pm 0.2^{\mathrm{abc}}$ & $0.4 \pm 0.2$ \\
\hline \multirow{4}{*}{3} & 25 & $15.6 \pm 1.1^{\mathrm{ab}}$ & $12.3 \pm 1.4^{\mathrm{cd}}$ & $17.1 \pm 1.0^{\mathrm{cd}}$ & $9.4 \pm 0.8^{\mathrm{cd}}$ & $75.9 \pm 4.5^{\text {efg }}$ & $31.0 \pm 1.7^{g}$ & $31.2 \pm 2.5^{c}$ & $97.2 \pm 7.1^{b}$ & $2.8 \pm 0.4^{b c}$ & $0.6 \pm 0.2$ \\
\hline & 15 & $23.1 \pm 2.3^{b c d}$ & $8.3 \pm 0.3^{a b c}$ & $16.2 \pm 0.6^{\mathrm{cd}}$ & $6.8 \pm 0.5^{a b c}$ & $41.3 \pm 3.2^{\mathrm{bcd}}$ & $24.9 \pm 1.0^{\mathrm{def}}$ & $16.0 \pm 1.4^{\mathrm{ab}}$ & $79.5 \pm 6.2^{\mathrm{ab}}$ & $1.7 \pm 0.3^{a b c}$ & $0.6 \pm 0.2$ \\
\hline & 10 & $18.0 \pm 0.9^{\mathrm{ab}}$ & $6.7 \pm 0.8^{a b c}$ & $8.8 \pm 0.5^{a b}$ & $8.3 \pm 0.9 \mathrm{bcd}$ & $32.1 \pm 3.0^{a b c}$ & $18.7 \pm 1.6^{\mathrm{abc}}$ & $13.3 \pm 2.1^{\mathrm{a}}$ & $72.3 \pm 4.2^{\mathrm{ab}}$ & $0.4 \pm 0.2^{\mathrm{a}}$ & $0.4 \pm 0.1$ \\
\hline & 5 & $14.4 \pm 0.7^{\mathrm{a}}$ & $3.6 \pm 0.4^{\mathrm{a}}$ & $4.5 \pm 0.2^{\mathrm{a}}$ & $14.6 \pm 1.2^{\mathrm{e}}$ & $14.3 \pm 1.4^{\mathrm{a}}$ & $20.0 \pm 0.9^{\mathrm{bcd}}$ & $25.6 \pm 1.5^{c}$ & $73.5 \pm 5.3^{a b}$ & $0.5 \pm 0.1^{\mathrm{a}}$ & $0.1 \pm 0.1$ \\
\hline \multirow{2}{*}{ Significance } & Storage & $* * *$ & $* * *$ & $* * *$ & $* *$ & $* * *$ & $* * *$ & $* * *$ & ns & $\mathrm{ns}$ & $\mathrm{ns}$ \\
\hline & FT & $* * *$ & $* * *$ & $* * *$ & $* * *$ & $* * *$ & $* * *$ & $* * *$ & $* *$ & $* * *$ & * \\
\hline
\end{tabular}

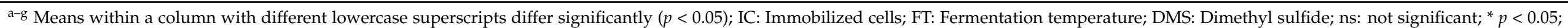

${ }^{* *} p<0.01 ;{ }^{* * *} p<0.001$. 
Table 2. Major volatile compounds in beers produced using thermally dried immobilized S. cerevisiae on peanut shells.

\begin{tabular}{|c|c|c|c|c|c|c|c|c|c|c|c|}
\hline $\begin{array}{l}\text { Storage of IC } \\
\text { (Months) }\end{array}$ & $\begin{array}{l}\text { FT } \\
\left({ }^{\circ} \mathrm{C}\right)\end{array}$ & $\begin{array}{l}\text { Diacetyl } \\
\left(\mu \mathrm{g} \mathrm{L}^{-1}\right)\end{array}$ & $\begin{array}{c}2,3- \\
\text { Pentanedione } \\
\left(\mu \mathrm{g} \mathrm{L}^{-1}\right)\end{array}$ & $\begin{array}{c}\text { DMS } \\
\left(\mu \mathrm{g} \mathrm{L}^{-1}\right)\end{array}$ & $\begin{array}{l}\text { Acetaldehyde } \\
\left(\mathrm{mg} \mathrm{L}^{-1}\right)\end{array}$ & $\begin{array}{c}\text { Ethyl } \\
\text { Acetate } \\
\left(\mathrm{mg} \mathrm{L}^{-1}\right)\end{array}$ & $\begin{array}{l}\text { Propanol } \\
\left(\mathrm{mg} \mathrm{L}^{-1}\right)\end{array}$ & $\begin{array}{l}\text { Isobutyl } \\
\text { Alcohol } \\
\left(\mathrm{mg} \mathrm{L}^{-1}\right)\end{array}$ & $\begin{array}{c}\text { Amyl } \\
\text { Alcohol } \\
\left(\mathrm{mg} \mathrm{L}^{-1}\right)\end{array}$ & $\begin{array}{l}\text { Isoamyl } \\
\text { Acetate } \\
\left(\mathrm{mg} \mathrm{L}^{-1}\right)\end{array}$ & $\begin{array}{c}\text { Ethyl } \\
\text { Hexanoate } \\
\left(\mathrm{mg} \mathrm{L}^{-1}\right)\end{array}$ \\
\hline \multirow{4}{*}{0} & 25 & $62.3 \pm 1.2^{\mathrm{e}}$ & $60.2 \pm 4.6^{d}$ & $48.2 \pm 3.0^{\mathrm{e}}$ & $5.4 \pm 0.5^{\mathrm{bcd}}$ & $60.9 \pm 10.2^{c}$ & $37.2 \pm 1.2^{\mathrm{ce}}$ & $36.6 \pm 2.0^{f}$ & $121.2 \pm 10.2^{\mathrm{d}}$ & $5.8 \pm 0.2^{\mathrm{d}}$ & $0.7 \pm 0.2$ \\
\hline & 15 & $92.1 \pm 4.2^{\mathrm{f}}$ & $39.4 \pm 2.1^{\mathrm{c}}$ & $27.2 \pm 1.4^{\mathrm{cd}}$ & $3.6 \pm 0.4^{\mathrm{ab}}$ & $40.8 \pm 5.5^{a b c}$ & $34.8 \pm 2.0$ dce & $26.1 \pm 1.5^{\mathrm{de}}$ & $102.0 \pm 9.4^{\mathrm{cd}}$ & $4.0 \pm 0.7^{\mathrm{cd}}$ & $0.8 \pm 0.1$ \\
\hline & 10 & $92.4 \pm 3.2^{f}$ & $14.4 \pm 1.8^{\mathrm{ab}}$ & $17.3 \pm 0.5^{a b}$ & $6.3 \pm 0.7^{\mathrm{bcd}}$ & $24.0 \pm 2.1^{\mathrm{a}}$ & $29.8 \pm 0.5^{\mathrm{cd}}$ & $19.8 \pm 0.9^{b c d}$ & $106.8 \pm 9.7^{\mathrm{cd}}$ & $1.4 \pm 0.2^{\mathrm{ab}}$ & $0.4 \pm 0.1$ \\
\hline & 5 & $27.6 \pm 2.1^{a b}$ & $12.5 \pm 0.9^{a b}$ & $16.2 \pm 0.4^{\mathrm{a}}$ & $7.3 \pm 0.8^{\mathrm{d}}$ & $17.9 \pm 1.2^{\mathrm{a}}$ & $13.7 \pm 1.0^{\mathrm{a}}$ & $24.5 \pm 1.5^{\text {cde }}$ & $68.0 \pm 5.2^{a b c}$ & $0.2 \pm 0.1^{\mathrm{a}}$ & $0.1 \pm 0.1$ \\
\hline \multirow{3}{*}{1} & 25 & $69.2 \pm 2.3^{\mathrm{e}}$ & $24.0 \pm 1.9 \mathrm{bc}$ & $43.5 \pm 3.1^{\mathrm{e}}$ & $4.2 \pm 0.4 \mathrm{abcd}$ & $57.9 \pm 9.7^{c}$ & $38.8 \pm 0.6^{\mathrm{e}}$ & $32.4 \pm 2.3^{\text {ef }}$ & $107.9 \pm 7.8^{\mathrm{cd}}$ & $4.3 \pm 0.6^{\mathrm{cd}}$ & $0.9 \pm 0.2$ \\
\hline & 10 & $38.4 \pm 2.8^{\mathrm{bcd}}$ & $21.5 \pm 0.7^{\mathrm{ab}}$ & $28.4 \pm 1.8^{\mathrm{cd}}$ & $4.6 \pm 0.6^{\mathrm{abcd}}$ & $25.4 \pm 2.2^{\mathrm{ab}}$ & $25.2 \pm 0.7^{b c}$ & $16.1 \pm 2.0^{\mathrm{abc}}$ & $91.4 \pm 8.1^{\mathrm{abcd}}$ & $0.8 \pm 0.1^{\mathrm{a}}$ & $0.2 \pm 0.1$ \\
\hline & 5 & $30.3 \pm 0.9 \mathrm{abc}$ & $20.6 \pm 2.3^{a b}$ & $20.8 \pm 0.9 \mathrm{abc}$ & $5.3 \pm 0.4 \mathrm{bcd}$ & $20.2 \pm 2.0^{\mathrm{a}}$ & $13.5 \pm 0.2^{\mathrm{a}}$ & $18.5 \pm 1.5^{\mathrm{abcd}}$ & $58.3 \pm 6.2^{\mathrm{ab}}$ & $0.2 \pm 0.1^{\mathrm{a}}$ & $0.7 \pm 0.2$ \\
\hline \multirow{4}{*}{3} & 25 & $44.9 \pm 3.2^{\mathrm{cd}}$ & $55.6 \pm 4.0^{d}$ & $32.1 \pm 0.7^{\mathrm{d}}$ & $6.9 \pm 0.9^{\mathrm{cd}}$ & $55.0 \pm 7.4^{b c}$ & $33.5 \pm 1.9$ dce & $26.3 \pm 1.2 \mathrm{de}$ & $94.3 \pm 8.6^{\mathrm{abcd}}$ & $5.3 \pm 0.4^{\mathrm{d}}$ & $1.0 \pm 0.1$ \\
\hline & 15 & $20.6 \pm 1.2^{\mathrm{a}}$ & $27.7 \pm 3.1 \mathrm{bc}$ & $22.0 \pm 1.6^{\mathrm{abc}}$ & $2.1 \pm 0.3^{\mathrm{a}}$ & $36.0 \pm 4.2^{a b c}$ & $22.4 \pm 0.9^{b}$ & $16.8 \pm 1.0^{a b c}$ & $69.8 \pm 5.6^{a b c}$ & $3.1 \pm 0.2^{b c}$ & $0.7 \pm 0.2$ \\
\hline & 10 & $90.1 \pm 4.5^{f}$ & $21.1 \pm 3.5^{\mathrm{ab}}$ & $20.9 \pm 2.1^{a b c}$ & $3.9 \pm 0.4^{\mathrm{abc}}$ & $30.1 \pm 3.2^{a b c}$ & $22.5 \pm 0.7^{b}$ & $15.7 \pm 2.1^{a b}$ & $84.8 \pm 7.9 \mathrm{abcd}$ & $1.1 \pm 0.3^{\mathrm{ab}}$ & $0.3 \pm 0.1$ \\
\hline & 5 & $46.5 \pm 2.7^{\mathrm{d}}$ & $7.2 \pm 0.2^{\mathrm{a}}$ & $17.0 \pm 1.4^{\mathrm{a}}$ & $4.3 \pm 0.4^{\mathrm{abcd}}$ & $21.0 \pm 3.0^{\mathrm{a}}$ & $12.3 \pm 0.2^{\mathrm{a}}$ & $10.5 \pm 0.9^{a}$ & $55.5 \pm 4.6^{\mathrm{a}}$ & $0.5 \pm 0.2^{\mathrm{a}}$ & $0.1 \pm 0.1$ \\
\hline Significance & Storage & $* * *$ & $* *$ & $* * *$ & $*$ & ns & $* * *$ & $* * *$ & $* *$ & ns & ns \\
\hline
\end{tabular}

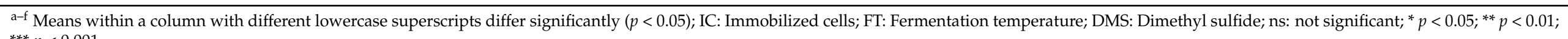
${ }^{* * *} p<0.001$. 
Esters are produced in low concentrations in beer, however, due to their low threshold values, their overproduction should be avoided, since the beer aroma can be negatively affected [31]. Ethyl acetate is the most important ester in beer representing almost the 33\% of total esters. In the present study only at low temperatures $\left(5-10^{\circ} \mathrm{C}\right)$ its concentration was below threshold value revealing that fermentation at higher temperatures is difficult to be controlled. Isoamyl acetate, having a banana-fruity aroma, and ethyl hexanoate, with apple-fruity aroma, are also important esters in beer. Both of them were detected at concentrations similar or below their threshold values especially at low temperatures [31].

Dimethyl sulfide (DMS), as the majority of unpleasant sulfury flavors, originates mainly from wort and hops, however, another possible origin is dimethyl sulfoxide (DMSO) by yeast during fermentation or wort-spoilage bacteria [33]. DMS may significantly affect the aroma of beer and may lead to undesirable flavor impressions like cooked cabbage or sweet-corn $[29,33]$. In the present study, its concentration was affected significantly $(p<0.001)$ by immobilization support, storage of immobilized cells and fermentation temperature. More specifically, lower concentrations were reported at lower fermentation temperatures (as in previous studies [29]), after storage of immobilized cells for three months and in the case of coconut shells. In almost all cases, the concentration of DMS was below its threshold value of $30 \mu \mathrm{g} \mathrm{L}^{-1}$, and therefore no defect in aroma was expected. Similar results were reported in lambic beers, where DMS was detected in small amounts only after extensive storage [34].

In beer, several vicinal diketones are produced as fermentation by-products and among them diacetyl (2,3-butanedione) and 2,3-pentanedione may play the most important role in the final flavor [30]. They are originated from two amino acids namely valine and leucine, and are responsible for toffee, butterscotch, honey and vanilla-like off-flavors when they are present at concentrations higher than their threshold values $\left(>0.1-0.4 \mathrm{mg} \mathrm{L}^{-1}\right)[29,34]$. In the present study, in all cases their concentrations were relatively lower than their threshold values and a reduction was observed at low fermentation temperatures. As in the case of DMS, immobilized cells on coconut shells resulted in significantly lower concentrations of diacetyl and 2,3-pentanedione.

\subsubsection{GC-MS Analysis of Beers}

The results of GC-MS analysis of beers are presented in Tables S1 and S2. Volatile acids are usually present in beer and among them acetic acid is the main compound [35]. In the present study, acetic acid ranged between 2.00 and $5.20 \mathrm{mg} \mathrm{L}^{-1}$, which is significantly lower than the usual range in beers and its threshold value [35]. An increase was observed with the decrease of the fermentation temperature, as was also reported in other studies [29,36]. The other five acids were detected, namely butanoic, hexanoic, octanoic, nonanoic and decanoic acid, but in relatively lower concentrations, below their threshold concentrations, which are higher than $5 \mathrm{mg} \mathrm{L}^{-1}$ [36]. No significant differences were reported in their content among the two different immobilization supports, while in their majority a slight increase was reported with the increase of fermentation temperature.

The most abundant volatile compound in beer is higher alcohols. They are mainly produced through the catabolism of amino acids by the yeast using Ehrlich pathway [31]. Apart from ethanol, other alcohols detected in the present study were propanol, 3-methylpropanol, 2- and 3-methyl-butanol and 2-phenylethanol. In all cases, an increase of fermentation temperature led to increase in their concentrations. High concentrations of higher alcohols may cause problem in the beer aroma, however, their high threshold values (>50 $\mathrm{mg} \mathrm{L}^{-1}$ ) in combination with their low content was not a problem in the present study. One of the few alcohols that provides a positive aroma to beer (sweet and rose flavors) is 2-phenylethanol [36]. However, in the present study, its concentration (7.5-20.2 $\mathrm{mg} \mathrm{L}^{-1}$ ) were below the threshold value $\left(40 \mathrm{mg} \mathrm{L}^{-1}\right)$ [31].

Compared to the other volatile compounds in beer, originating from yeast metabolism, esters are only trace elements [31]. In the present study, nine esters were detected and the majority of them belongs to the group of ethyl esters. Esters are responsible for a 
fruit-like and floral flavor [36]. Their low threshold values make them important aromatic compounds in beer, but also possible off-flavorings in the case of overproduction [31]. In the present study, ethyl octanoate and ethyl decanoate, responsible for apple aroma, were detected in concentrations (0.4-1.9 $\mathrm{mg} \mathrm{L}^{-1}$ and $0.7-4.4 \mathrm{mg} \mathrm{L}^{-1}$, respectively) higher than the threshold value $\left(0.5 \mathrm{mg} \mathrm{L}^{-1}\right.$ and $1.5 \mathrm{mg} \mathrm{L}^{-1}$, respectively).

In Tables 3 and 4, the effect of immobilization supports in combination with fermentation temperature and storage of immobilized cells, on major volatile groups of beers, as detected by GC-MS analysis, is presented. Fermentation temperature affected significantly $(p<0.001)$ esters, alcohols and total compounds. In general, high fermentation temperatures resulted in higher concentrations. It is well-known that increasing fermentation temperature also increases the expression of the gene that is responsible for the increased transport of amino acids into yeast cells [31]. The high availability of amino acids favors the production of higher alcohols through the Ehrlich pathway [32,37]. The effect of storage of thermally-dried immobilized cells for up to three months affected significantly all volatile groups. The effect of different immobilization support was not significant in the majority of the cases. Finally, the higher alcohols-to-esters ratio was in all cases higher in peanut shells. In addition, in both supports, an increase, with the decrease of fermentation temperature, was reported, while no significant effect was observed by the storage of immobilized cells. In general, this means that immobilized cells on coconut shells resulted in more fruity beers due to lower ratio of higher alcohols to esters.

Table 3. Effect of fermentation temperature on volatile compounds $\left(\mathrm{mg} \mathrm{L}^{-1}\right)$ of beers produced with thermally dried immobilized S. cerevisiae on peanut shells and coconut shells.

\begin{tabular}{|c|c|c|c|c|c|}
\hline Compound & $\begin{array}{c}\text { FT } \\
\left({ }^{\circ} \mathrm{C}\right)\end{array}$ & Esters & Acids & Alcohols & Total \\
\hline \multirow{4}{*}{$\begin{array}{l}\text { Peanut } \\
\text { shells }\end{array}$} & 25 & $38.01 \pm 2.77^{\mathrm{e}}$ & $5.21 \pm 0.49^{a b}$ & $142.60 \pm 8.06^{b c}$ & $185.82 \pm 5.78 \mathrm{de}$ \\
\hline & 15 & $28.87 \pm 0.51^{\mathrm{cd}}$ & $5.28 \pm 0.08^{a b}$ & $122.50 \pm 9.90^{a b c}$ & $156.65 \pm 10.49 \mathrm{bcd}$ \\
\hline & 10 & $24.11 \pm 0.86^{b c}$ & $5.28 \pm 0.51^{\mathrm{ab}}$ & $113.35 \pm 5.73^{a b}$ & $142.74 \pm 6.08^{a b c}$ \\
\hline & 5 & $17.85 \pm 1.12^{\mathrm{a}}$ & $6.16 \pm 0.40^{\mathrm{b}}$ & $99.50 \pm 2.90^{\mathrm{a}}$ & $123.51 \pm 2.18^{\mathrm{ab}}$ \\
\hline \multirow{4}{*}{$\begin{array}{l}\text { Coconut } \\
\text { shells }\end{array}$} & 25 & $46.09 \pm 0.49^{\mathrm{f}}$ & $5.54 \pm 0.28^{a b}$ & $150.80 \pm 16.55^{c}$ & $202.43 \pm 16.33^{\mathrm{e}}$ \\
\hline & 15 & $34.94 \pm 1.01^{\mathrm{e}}$ & $5.22 \pm 0.62^{a b}$ & $122.85 \pm 11.95^{a b c}$ & $163.01 \pm 13.58^{\mathrm{cd}}$ \\
\hline & 10 & $29.45 \pm 0.98^{\mathrm{d}}$ & $4.37 \pm 0.51^{\mathrm{a}}$ & $116.80 \pm 3.96^{a b c}$ & $150.62 \pm 3.49 \mathrm{abcd}$ \\
\hline & 5 & $21.12 \pm 0.86^{\mathrm{ab}}$ & $5.43 \pm 0.37^{\mathrm{ab}}$ & $88.30 \pm 7.21^{\mathrm{a}}$ & $114.85 \pm 6.72^{\mathrm{a}}$ \\
\hline \multirow{2}{*}{ Significance } & FT & $* * *$ & ns & $* * *$ & $* * *$ \\
\hline & IS & $* * *$ & ns & ns & ns \\
\hline
\end{tabular}

${ }^{\mathrm{a}-\mathrm{f}}$ Means within a column with different lowercase superscripts differ significantly $(p<0.05)$; (FT: Fermentation temperature; IS: Immobilization support); ${ }^{* * *} p<0.001$; ns: not significant.

Table 4. Effect of storage of thermally dried immobilized S. cerevisiae on peanut shells and coconut shells on volatile compounds $\left(\mathrm{mg} \mathrm{L}^{-1}\right)$ of beers.

\begin{tabular}{|c|c|c|c|c|c|}
\hline Compound & $\begin{array}{l}\text { Storage } \\
\text { (Months) }\end{array}$ & Esters & Acids & Alcohols & Total \\
\hline \multirow{3}{*}{$\begin{array}{l}\text { Peanut } \\
\text { shells }\end{array}$} & 0 & $28.87 \pm 0.51^{\mathrm{a}}$ & $5.28 \pm 0.08^{b}$ & $122.50 \pm 9.90$ & $156.65 \pm 10.49$ \\
\hline & 1 & $27.62 \pm 1.34^{\mathrm{a}}$ & $4.06 \pm 0.34^{\mathrm{ab}}$ & $121.66 \pm 2.47$ & $153.34 \pm 3.47$ \\
\hline & 3 & $24.09 \pm 2.72^{\mathrm{a}}$ & $3.64 \pm 0.44^{\mathrm{a}}$ & $108.13 \pm 7.17$ & $135.86 \pm 10.32$ \\
\hline \multirow{3}{*}{$\begin{array}{l}\text { Coconut } \\
\text { shells }\end{array}$} & 0 & $34.94 \pm 1.01^{b}$ & $5.22 \pm 0.62^{b}$ & $122.85 \pm 11.95$ & $163.01 \pm 13.58$ \\
\hline & 1 & $24.68 \pm 0.47^{\mathrm{a}}$ & $4.88 \pm 0.06^{\mathrm{ab}}$ & $117.41 \pm 5.81$ & $146.96 \pm 6.34$ \\
\hline & 3 & $25.56 \pm 0.47^{\mathrm{a}}$ & $4.43 \pm 0.09 \mathrm{ab}$ & $104.57 \pm 1.97$ & $134.55 \pm 1.60$ \\
\hline \multirow{2}{*}{ Significance } & Storage & $* * *$ & $* *$ & $*$ & $*$ \\
\hline & IS & ns & $*$ & ns & ns \\
\hline
\end{tabular}

a,b Means within a column with different lowercase superscripts differ significantly $(p<0.05)$; (IS: Immobilization support); ${ }^{*} p<0.05$;

${ }^{* *} p<0.01 ;{ }^{* * *} p<0.001 ;$ ns: not significant. 


\subsection{Fermented Milks}

The major aroma-related compounds of fermented milks with thermally-dried immobilized L. casei cells on coconut and peanut shells were detected using SPME GC-MS analysis (Tables S3 and S4). Two factors were evaluated namely fermentation time and storage. More specifically, fermentation at 37,18 and $10{ }^{\circ} \mathrm{C}$ were conducted using thermally dried immobilized cells. The effect of storage was also evaluated and for this reason thermally-dried immobilized cells were stored at $5{ }^{\circ} \mathrm{C}$ for up to three months prior the fermentation of milk at $18{ }^{\circ} \mathrm{C}$. No significant differences were observed on the number of compounds detected in each sample.

Low numbers and low concentrations of esters were detected in all cases, a fact that is usual in fermented milk products without extended storage, like yogurts [38] and fermented milks [39,40].

Carboxyl acid compounds were, with ketones, the most abundant groups of volatile compounds in fermented milks of the present study. Indeed, organic acids are among the main volatile components of the majority of dairy products. Acetic acid was detected in all samples in similar concentrations and it is responsible for a vinegary taste in dairy products [41]. Hexanoic acid (cheesy, rancid, sweet-like flavor) had the highest concentration in all samples among acids and with butanoic, octanoic, nonanoic, and decanoic acid are usually found in dairy products [38-40,42]. In addition, the use of L. casei, either in free or immobilized form, has been correlated with the production of increased concentrations of these acids as was also observed in the present study $[38,39]$.

Alcohols is another group of volatile compounds important for the flavor of dairy products. Ethanol was detected in all samples in high concentrations as in numerous previous studies $[38,39,43]$. Other alcohols detected in the majority of samples were 1hexanol (fruity notes), 3-methyl-1-butanol (alcoholic and floral flavor), 2-heptanol and 2-nonanol. The only alcohol, apart from ethanol, that was detected in all samples was 2-ethyl-1-hexanol. The production of this alcohol has been correlated with the presence of L. case $i$ in dairy products like yogurts, cheese and fermented milks $[38,39,43]$.

Aldehydes are also important for the flavor of dairy products. Acetaldehyde (green apple and nutty flavor) is a key volatile compound responsible for the typical flavor and aroma of yogurts and fermented milks in general and therefore it is usually present in high concentrations. In the present study, in all cases, it ranged from 8.20 to $12.10 \mu \mathrm{g} \mathrm{kg}^{-1}$. These values are lower than previous studies with L. casei and yogurt starters $\left(15-19 \mu \mathrm{g} \mathrm{kg}^{-1}\right)[38,39]$ and even lower compared to studies with Lactobacillus delbrueckii subsp. bulgaricus (up to $74.5 \mu \mathrm{g} \mathrm{L}^{-1}$ ) [42]. These results may be explained by the low contribution of $L$. casei on acetaldehyde content observed in previous studies [35] and by the fact that in yogurts, Lactobacillus delbrueckii subsp. bulgaricus is mainly responsible for acetaldehyde production $[42,44]$. Other aldehydes detected were hexanal, heptanal, octanal and nonanal and [E]-2-nonenal.

Ketones presented the second highest concentration after acids. In total, nine ketone compounds were detected in the fermented milks of the present study. Acetone was produced mainly in higher temperatures $\left(18^{\circ} \mathrm{C}\right.$ and $\left.37^{\circ} \mathrm{C}\right)$ and it is known for its sweet and fruity aroma in yogurts. Methyl ketones are usually detected in dairy products and in the present study five methyl ketones were detected, namely 2-butanone, 2-pentanone, 2-heptanone, 2-undecanone, and 2-tridecanone. L. casei has been correlated with increased production in such compounds $[38,39,43]$ and this is also reported hereby. Among these compounds 2-pentanone had the highest concentration followed by 2-butanone and 2heptanone. The use of coconut shells led to higher concentrations of methyl ketones and the same was observed in higher fermentation temperatures. The ketone with the highest content in almost all samples was 3-hydroxy-2-butanone (acetoin). It is a well-known odorant of dairy products with creamy and buttery like flavor. Its concentration was higher in $18^{\circ} \mathrm{C}$ and in cells immobilized on coconut shells. Similar results were reported in the case of 2,3-butanedione (diacetyl) with a buttery flavor. Similar concentrations of ketones 
were reported in other studies with dairy products produced by free or immobilized $L$. casei $[38,39,43]$.

In Table 5, the effect of immobilization support and fermentation temperature on the concentrations of major volatile groups are presented. The effect of immobilization support (coconut or peanut shells) was not so important and affected only total compounds $(p<0.01)$, alcohols $(p<0.01)$ and esters $(p<0.05)$. The use of coconut shells led to increased content of esters and total compounds while peanut shells to increased content of alcohols. In the case of fermentation temperature, in general $18^{\circ} \mathrm{C}$ resulted in higher concentrations of all volatile groups. More specifically, fermentation temperature affected significantly $(p<0.001)$ acids and total compounds, less significantly alcohols $(p<0.01)$ and esters $(p<0.05)$, while it did not affect aldehydes and ketones.

Table 5. Effect of fermentation temperature on volatile compounds $\left(\mu \mathrm{g} \mathrm{kg}{ }^{-1}\right)$ of fermented milks produced with thermally dried immobilized L. casei on peanut shells and coconut shells.

\begin{tabular}{|c|c|c|c|c|c|c|c|}
\hline Compound & $\begin{array}{c}\text { FT } \\
\left({ }^{\circ} \mathrm{C}\right)\end{array}$ & Esters & Acids & Alcohols & Aldehydes & Ketones & Total \\
\hline \multirow{3}{*}{$\begin{array}{c}\text { Peanut } \\
\text { shells }\end{array}$} & 37 & $0.90 \pm 0.14^{\mathrm{ab}}$ & $191.15 \pm 3.04^{b}$ & $23.20 \pm 2.40^{a b c}$ & $48.80 \pm 1.70$ & $194.40 \pm 7.92$ & $458.45 \pm 9.12^{\mathrm{a}}$ \\
\hline & 18 & $0.30 \pm 0.14^{\mathrm{a}}$ & $269.30 \pm 6.65^{d}$ & $33.40 \pm 2.40^{c}$ & $50.00 \pm 3.11$ & $240.60 \pm 6.36$ & $593.60 \pm 18.67^{b c}$ \\
\hline & 10 & $0.40 \pm 0.28^{a}$ & $200.90 \pm 6.22^{b c}$ & $22.40 \pm 2.97^{a b}$ & $44.60 \pm 0.99$ & $153.60 \pm 4.24$ & $421.90 \pm 6.79^{a}$ \\
\hline \multirow{3}{*}{$\begin{array}{l}\text { Coconut } \\
\text { shells }\end{array}$} & 37 & $1.30 \pm 0.14^{\mathrm{ab}}$ & $220.80 \pm 4.53^{c}$ & $18.40 \pm 2.40^{a b}$ & $41.50 \pm 2.40$ & $286.80 \pm 8.34$ & $568.80 \pm 17.82^{b}$ \\
\hline & 18 & $1.60 \pm 0.57^{\mathrm{b}}$ & $266.00 \pm 1.27^{\mathrm{d}}$ & $27.30 \pm 3.68 \mathrm{bc}$ & $50.30 \pm 1.84$ & $295.20 \pm 11.46$ & $640.40 \pm 18.81^{\mathrm{c}}$ \\
\hline & 10 & $0.20 \pm 0.14^{\mathrm{a}}$ & $167.30 \pm 6.22^{\mathrm{a}}$ & $13.40 \pm 2.40^{\mathrm{a}}$ & $46.10 \pm 1.13$ & $180.00 \pm 10.47$ & $407.00 \pm 18.10^{a}$ \\
\hline \multirow{2}{*}{ Significance } & IS & * & ns & $* *$ & ns & ns & $* *$ \\
\hline & FT & * & $* * *$ & $* *$ & ns & ns & $* * *$ \\
\hline
\end{tabular}

a-d Means within a column with different lowercase superscripts differ significantly ( $p<0.05)$; FT: Fermentation temperature; IS: Immobilization support; ns: not significant; ${ }^{*} p<0.05 ; * * p<0.01 ;{ }^{* * *} p<0.001$.

As far as concerning the storage of thermally-dried immobilized cells, the results are presented at Table 6 . Storage and immobilization support affected all volatile groups apart from alcohols. More specifically, in both immobilization supports, storage of immobilized cells resulted in lower concentrations of all compounds and this may be attributed to the extended lag phase in the growth of dried cells. Finally, the use of coconut shells led to increased content at the majority of compounds.

Table 6. Effect of storage on volatile compounds $\left(\mu \mathrm{g} \mathrm{kg}^{-1}\right)$ of fermented milks produced with thermally-dried immobilized L. casei on peanut shells and coconut shells.

\begin{tabular}{|c|c|c|c|c|c|c|c|}
\hline Compound & $\begin{array}{l}\text { Storage } \\
\text { (Months) }\end{array}$ & Esters & Acids & Alcohols & Aldehydes & Ketones & Total \\
\hline \multirow{3}{*}{$\begin{array}{c}\text { Peanut } \\
\text { shells }\end{array}$} & 0 & $0.30 \pm 0.14^{\mathrm{a}}$ & $269.30 \pm 6.65^{c}$ & $33.40 \pm 2.40$ & $50.00 \pm 3.11^{c}$ & $240.60 \pm 6.36^{c}$ & $593.60 \pm 18.67^{d}$ \\
\hline & 1 & nd & $213.90 \pm 3.54^{\mathrm{a}}$ & $24.70 \pm 0.57$ & $38.60 \pm 2.12^{b}$ & $189.70 \pm 3.25^{b}$ & $466.90 \pm 2.97^{b}$ \\
\hline & 3 & nd & $218.20 \pm 4.38^{\mathrm{a}}$ & $13.20 \pm 0.99$ & $36.50 \pm 1.41^{b}$ & $127.70 \pm 4.10^{\mathrm{a}}$ & $395.60 \pm 10.89^{a}$ \\
\hline \multirow{3}{*}{$\begin{array}{l}\text { Coconut } \\
\text { shells }\end{array}$} & 0 & $1.60 \pm 0.57^{b}$ & $266.00 \pm 1.27^{c}$ & $27.30 \pm 3.68$ & $50.30 \pm 1.84^{c}$ & $295.20 \pm 11.46^{\mathrm{d}}$ & $640.40 \pm 18.81^{\mathrm{d}}$ \\
\hline & 1 & $0.60 \pm 0.28^{a b}$ & $238.50 \pm 5.23^{b}$ & $21.90 \pm 2.40$ & $25.20 \pm 0.42^{\mathrm{a}}$ & $243.05 \pm 7.82^{c}$ & $529.25 \pm 15.34^{c}$ \\
\hline & 3 & $0.20 \pm 0.14^{a}$ & $223.10 \pm 1.27^{a b}$ & $11.90 \pm 1.41$ & $31.50 \pm 1.98^{a b}$ & $179.50 \pm 9.05^{b}$ & $446.20 \pm 13.86^{a b}$ \\
\hline \multirow{2}{*}{ Significance } & IS & $* *$ & * & ns & $* *$ & $* * *$ & $* * *$ \\
\hline & Storage & * & $* * *$ & ns & $* * *$ & $* * *$ & $* * *$ \\
\hline
\end{tabular}

${ }^{\mathrm{a}-\mathrm{d}}$ Means within a column with different lowercase superscripts differ significantly $(p<0.05)$; IS: Immobilization support; ns: not significant; nd: not detected; ${ }^{*} p<0.05 ;{ }^{* *} p<0.01 ;{ }^{* *} p<0.001$.

\section{Conclusions}

In the present study, a sustainable exploitation of coconut and peanut shells is proposed through the production of carriers for yeast and bacteria and applications in food industry. Both carriers evaluated for immobilization proved suitable for beer and milk 
fermentations. The aroma of both products was similar with other studies while, in general, coconut shells resulted in better products. The immobilized cells proved capable for satisfactory fermentations in a wide range of fermentation temperatures and even after storage for up to three months. However, more research is needed in order to evaluate the effect of immobilized cells on the sensory characteristics of the products and in possible applications on continuous systems. Finally, especially in the case of fermented milks, the possible prebiotic effect of the materials in combination with increased survival of probiotic cells under gastrointestinal conditions in vitro and in vivo need to be proved.

Supplementary Materials: The following are available online at https: / www.mdpi.com/article/ 10.3390/beverages7030047/s1, Table S1: Volatile compounds $\left(\mathrm{mg} \mathrm{L}^{-1}\right)$ of beers (GC-MS analysis) with thermally-dried immobilized S. cerevisiae cells on tubular cellulose from coconut shells; Table S2: Volatile compounds ( $\mathrm{mg} \mathrm{L}^{-1}$ ) of beers (GC-MS analysis) with thermally-dried immobilized S. cerevisiae cells on tubular cellulose from peanut shells; Table S3: Volatile compounds $\left(\mathrm{mg} \mathrm{kg}^{-1}\right)$ of fermented milks (GC-MS analysis) with thermally-dried immobilized L. casei cells on tubular cellulose from coconut shells; Table S4: Volatile compounds $\left(\mathrm{mg} \mathrm{kg}^{-1}\right)$ of fermented milks (GC-MS analysis) with thermally-dried immobilized L. casei cells on tubular cellulose from peanut shells.

Author Contributions: Conceptualization, D.D. and M.K.; methodology, P.K. and D.D.; validation, P.K. and D.D.; formal analysis, P.K.; investigation, M.G., E.K. and D.D.; resources, M.K.; data curation, P.K. and D.D.; writing—original draft preparation, P.K. and D.D.; writing—review and editing, P.K. and D.D.; visualization, P.K. and D.D.; supervision, D.D. and M.K.; project administration, D.D. and M.K.; funding acquisition, M.K. All authors have read and agreed to the published version of the manuscript.

Funding: This research was implemented under the "ARISTEIA" Action of the "Operational Program Education and Lifelong Learning" and was co-funded by the European Social Fund (ESF) and Greek National Resources.

Institutional Review Board Statement: Not applicable.

Informed Consent Statement: Not applicable.

Data Availability Statement: The data presented in this study are available in the Supplementary files.

Acknowledgments: The authors would like to thank the Athenian Brewery S.A. for wort supply and technical support.

Conflicts of Interest: The authors declare no conflict of interest. The funders had no role in the design of the study; in the collection, analyses, or interpretation of data; in the writing of the manuscript, or in the decision to publish the results.

\section{References}

1. Sadh, P.K.; Duhan, S.; Duhan, J.S. Agro-industrial wastes and their utilization using solid state fermentation: A review. Bioresour. Bioprocess. 2018, 5, 1-15. [CrossRef]

2. Prakash, A.; Vadivel, V.; Banu, S.F.; Nithyanand, P.; Lalitha, C.; Brindha, P. Evaluation of antioxidant and antimicrobial properties of solvent extracts of agro-food by-products (cashew nut shell, coconut shell and groundnut hull). Agric. Nat. Resour. 2018, 52, 451-459. [CrossRef]

3. Bharthare, P.; Shrivastava, P.; Singh, P.; Ttiwari, A. Peanut shell as renewable energy source and their utility in production of ethanol. Int. J. Adv. Res. 2014, 2, 1-14.

4. Daud, W.M.A.W. Comparison on pore development of activated carbon produced from palm shell and coconut shell. Bioresour. Technol. 2004, 93, 63-69. [CrossRef]

5. Pappu, A.; Saxena, M.; Asolekar, S.R. Solid wastes generation in India and their recycling potential in building materials. Build. Environ. 2007, 42, 2311-2320. [CrossRef]

6. Madurwar, M.V.; Ralegaonkar, R.V.; Mandavgane, S.A. Application of agro-waste for sustainable construction materials: A review. Constr. Build. Mater. 2013, 38, 872-878. [CrossRef]

7. Kulkarni, S.J.; Tapre, R.W.; Patil, S.V.; Sawarkar, M.B. Adsorption of Phenol from Wastewater in Fluidized Bed Using Coconut Shell Activated Carbon. Procedia Eng. 2013, 51, 300-307. [CrossRef]

8. Taşar, Ş.; Kaya, F.; Özer, A. Biosorption of lead (II) ions from aqueous solution by peanut shells: Equilibrium, thermodynamic and kinetic studies. J. Environ. Chem. Eng. 2014, 2, 1018-1026. [CrossRef] 
9. Widiyastuti, W.; Rois, M.F.; Suari, N.M.I.P.; Setyawan, H. Activated carbon nanofibers derived from coconut shell charcoal for dye removal application. Adv. Powder Technol. 2020, 31, 3267-3273. [CrossRef]

10. Liu, J.; Wang, Z.; Li, H.; Hu, C.; Raymer, P.; Huang, Q. Effect of solid state fermentation of peanut shell on its dye adsorption performance. Bioresour. Technol. 2018, 249, 307-314. [CrossRef]

11. Sattar, M.S.; Shakoor, M.B.; Ali, S.; Rizwan, M.; Niazi, N.K.; Jilani, A. Comparative efficiency of peanut shell and peanut shell biochar for removal of arsenic from water. Environ. Sci. Pollut. Res. 2019, 26, 18624-18635. [CrossRef] [PubMed]

12. Goel, J.; Kadirvelu, K.; Rajagopal, C. Mercury (II) removal from water by coconut shell based activated carbon: Batch and column studies. Environ. Technol. 2004, 25, 141-153. [CrossRef] [PubMed]

13. Zhao, F.; Zou, G.; Shan, Y.; Ding, Z.; Dai, M.; He, Z. Coconut shell derived biochar to enhance water spinach (Ipomoea aquatica Forsk) growth and decrease nitrogen loss under tropical conditions. Sci. Rep. 2019, 9, 20291. [CrossRef]

14. Xu, C.-Y.; Bai, S.H.; Hao, Y.; Rachaputi, R.C.N.; Xu, Z.; Wallace, H. Peanut shell biochar improves soil properties and peanut kernel quality on a red Ferrosol. J. Soils Sediments 2015, 15, 2220-2231. [CrossRef]

15. Panitsa, A.; Petsi, T.; Kandylis, P.; Nigam, P.S.; Kanellaki, M.; Koutinas, A.A. Chemical preservative delivery in meat using edible vegetable tubular cellulose. LWT 2021, 141, 111049. [CrossRef]

16. Peña-Gómez, N.; Panagopoulos, V.; Kanellaki, M.; Koutinas, A.A.; Ruiz-Rico, M.; Fernández-Segovia, I.; Barat, J.M. Non-thermal treatment for the stabilisation of liquid food using a tubular cellulose filter from corn stalks. Food Control. 2020, 112, 107164. [CrossRef]

17. Kumar, M.; Gialleli, A.-I.; Masson, J.B.; Kandylis, P.; Bekatorou, A.; Koutinas, A.A.; Kanellaki, M. Lactic acid fermentation by cells immobilised on various porous cellulosic materials and their alginate/poly-lactic acid composites. Bioresour. Technol. 2014, 165, 332-335. [CrossRef]

18. Torres-García, E.; Ramírez-Verduzco, L.; Aburto, J. Pyrolytic degradation of peanut shell: Activation energy dependence on the conversion. Waste Manag. 2020, 106, 203-212. [CrossRef]

19. Orzua, M.C.; Mussatto, S.I.; Contreras-Esquivel, J.C.; Rodriguez, R.; de la Garza, H.; Teixeira, J.A.; Aguilar, C.N. Exploitation of agro industrial wastes as immobilization carrier for solid-state fermentation. Ind. Crop. Prod. 2009, 30, 24-27. [CrossRef]

20. Gialleli, A.-I.; Ganatsios, V.; Terpou, A.; Kanellaki, M.; Bekatorou, A.; Koutinas, A.A.; Dimitrellou, D. Technological Development of Brewing in Domestic Refrigerator Using Freeze-Dried Raw Materials. Food Technol. Biotechnol. 2017, 55, 325-332. [CrossRef] [PubMed]

21. Terpou, A.; Gialleli, A.-I.; Bekatorou, A.; Dimitrellou, D.; Ganatsios, V.; Barouni, E.; Koutinas, A.A.; Kanellaki, M. Sour milk production by wheat bran supported probiotic biocatalyst as starter culture. Food Bioprod. Process. 2017, 101, 184-192. [CrossRef]

22. Kandylis, P.; Dimitrellou, D.; Koutinas, A.A. Winemaking by barley supported yeast cells. Food Chem. 2012, 130, 425-431. [CrossRef]

23. Dimitrellou, D.; Tsaousi, K.; Kourkoutas, Y.; Panas, P.; Kanellaki, M.; Koutinas, A.A. Fermentation efficiency of thermally dried immobilized kefir on casein as starter culture. Process Biochem. 2008, 43, 1323-1329. [CrossRef]

24. Barouni, E.; Petsi, T.; Kanellaki, M.; Bekatorou, A.; Koutinas, A. Tubular cellulose/starch gel composite as food enzyme storehouse. Food Chem. 2015, 188, 106-110. [CrossRef]

25. Dimitrellou, D.; Kourkoutas, Y.; Koutinas, A.; Kanellaki, M. Thermally-dried immobilized kefir on casein as starter culture in dried whey cheese production. Food Microbiol. 2009, 26, 809-820. [CrossRef] [PubMed]

26. Rosa, M.; Medeiros, E.; Malmonge, J.; Gregorski, K.; Wood, D.; Mattoso, L.; Glenn, G.; Orts, W.; Imam, S. Cellulose nanowhiskers from coconut husk fibers: Effect of preparation conditions on their thermal and morphological behavior. Carbohydr. Polym. 2010, 81, 83-92. [CrossRef]

27. Avelino, F.; da Silva, K.T.; Filho, M.D.S.M.D.S.; Mazzetto, S.E.; Lomonaco, D. Microwave-assisted organosolv extraction of coconut shell lignin by Brønsted and Lewis acids catalysts. J. Clean. Prod. 2018, 189, 785-796. [CrossRef]

28. Fang, Z.F.; Liu, K.L.; Chen, F.S.; Zhang, L.F.; Guo, Z. Cationic surfactant-assisted microwave-NaOH pretreatment for en-hancing enzymatic hydrolysis and fermentable sugar yield from peanut shells. BioResources 2014, 9, 1290-1302. [CrossRef]

29. Kopsahelis, N.; Kanellaki, M.; Bekatorou, A. Low temperature brewing using cells immobilized on brewer's spent grains. Food Chem. 2007, 104, 480-488. [CrossRef]

30. Bekatorou, A.; Soupioni, M.J.; A Koutinas, A.; E Kanellaki, M. Low-temperature brewing by freeze-dried immobilized cells. Appl. Biochem. Biotechnol. 2002, 97, 105-122. [CrossRef]

31. Pires, E.J.; Teixeira, J.A.; Brányik, T.; Vicente, A.A. Yeast: The soul of beer's aroma-A review of flavour-active esters and higher alcohols produced by the brewing yeast. Appl. Microbiol. Biotechnol. 2014, 98, 1937-1949. [CrossRef]

32. Saerens, S.M.G.; Verbelen, P.J.; Vanbeneden, N.; Thevelein, J.M.; Delvaux, F.R. Monitoring the influence of high-gravity brewing and fermentation temperature on flavour formation by analysis of gene expression levels in brewing yeast. Appl. Microbiol. Biotechnol. 2008, 80, 1039-1051. [CrossRef]

33. Kucharczyk, K.; Żyła, K.; Tuszyński, T. Simultaneous Optimization of Acetaldehyde and DMS Concentrations for Better Sensory Quality of Beer Fermented on an Industrial Scale. Foods 2020, 9, 1043. [CrossRef] [PubMed]

34. Witrick, K.; Pitts, E.R.; O'Keefe, S.F. Analysis of Lambic Beer Volatiles during Aging Using Gas Chromatography-Mass Spectrometry (GCMS) and Gas Chromatography-Olfactometry (GCO). Beverages 2020, 6, 31. [CrossRef]

35. Zhang, Y.; Jia, S.; Zhang, W. Predicting acetic acid content in the final beer using neural networks and support vector machine. J. Inst. Brew. 2012, 118, 361-367. [CrossRef] 
36. Šmogrovičová, D.; Dömény, Z. Beer volatile by-product formation at different fermentation temperature using immobilised yeasts. Process. Biochem. 1999, 34, 785-794. [CrossRef]

37. Kodama, Y.; Omura, F.; Miyajima, K.; Ashikari, T. Control of Higher Alcohol Production by Manipulation of theBAP2Gene in Brewing Yeast. J. Am. Soc. Brew. Chem. 2001, 59, 157-162. [CrossRef]

38. Dimitrellou, D.; Kandylis, P.; Kourkoutas, Y. Assessment of Freeze-Dried Immobilized Lactobacillus casei as Probiotic Adjunct Culture in Yogurts. Foods 2019, 8, 374. [CrossRef]

39. Dimitrellou, D.; Kandylis, P.; Lević, S.; Petrović, T.; Ivanović, S.; Nedović, V.; Kourkoutas, Y. Encapsulation of Lactobacillus casei ATCC 393 in alginate capsules for probiotic fermented milk production. LWT 2019, 116, 108501. [CrossRef]

40. Cheng, H. Volatile Flavor Compounds in Yogurt: A Review. Crit. Rev. Food Sci. Nutr. 2010, 50, 938-950. [CrossRef]

41. Dan, T.; Wang, D.; Wu, S.; Jin, R.; Ren, W.; Sun, T. Profiles of Volatile Flavor Compounds in Milk Fermented with Different Proportional Combinations of Lactobacillus delbrueckii subsp. bulgaricus and Streptococcus thermophilus. Molecules 2017, 22, 1633. [CrossRef]

42. Dan, T.; Ren, W.; Liu, Y.; Tian, J.; Chen, H.; Li, T.; Liu, W. Volatile Flavor Compounds Profile and Fermentation Characteristics of Milk Fermented by Lactobacillus delbrueckii subsp. bulgaricus. Front. Microbiol. 2019, 10, 2183. [CrossRef] [PubMed]

43. Dimitrellou, D.; Kandylis, P.; Kourkoutas, Y.; Kanellaki, M. Novel probiotic whey cheese with immobilized lactobacilli on casein. LWT 2017, 86, 627-634. [CrossRef]

44. Zourari, A.; Accolas, J.P.; Desmazeaud, M.J. Metabolism and biochemical characteristics of yogurt bacteria. A review. Le Lait 1992, 72, 1-34. [CrossRef] 